\title{
An overview on amyotrophic lateral sclerosis and cadmium
}

\author{
Riccardo Oggiano ${ }^{1} \cdot$ Andrea Pisano $^{1} \cdot$ Angela Sabalic $^{1} \cdot$ Cristiano Farace $^{1,2} \cdot$ Grazia Fenu $^{1} \cdot$ Simone Lintas ${ }^{1}$. \\ Giovanni Forte $^{3} \cdot$ Beatrice Bocca $^{3} \cdot$ Roberto Madeddu $^{1,2}$ (D)
}

Received: 14 July 2020 / Accepted: 1 December 2020 / Published online: 5 December 2020

(C) The Author(s) 2020

\begin{abstract}
The present review represents an update about the knowledge of the possible role of Cadmium $(\mathrm{Cd})$ in amyotrophic lateral sclerosis (ALS) initiation and its progression. ALS is a neurodegenerative disease that occurs in adulthood; its etiology is unknown and leads to death within a few years from its appearance. Among the various possible causes that can favor the development of the disease, heavy metals cannot be excluded. Cadmium is a heavy metal that does not play a biological role, but its neurotoxicity is well known. Numerous in vitro studies on cell and animal models confirm the toxicity of the metal on the nervous system, but these data are not accompanied by an epidemiological evidence, and, thus, an unclear correlation between $\mathrm{Cd}$ and the onset of the disease can be pointed out. On the other hand, a possible multifactorial and synergic mechanism in which $\mathrm{Cd}$ may have a role can explain the ALS onset. More efforts in new clinical, biochemical, and epidemiological studies are necessary to better elucidate the involvement of $\mathrm{Cd}$ in this lethal disease.
\end{abstract}

Keywords Amyotrophic lateral sclerosis $\cdot$ Cadmium $\cdot$ Motor neuron disease $\cdot$ Heavy metals $\cdot$ Neurodegenerative disease

\section{Introduction}

Amyotrophic lateral sclerosis (ALS) is a fatal neurodegenerative disease that occurs in adulthood. It is characterized by the progressive loss of motor neurons in the motor cortex, brain stem, and spinal cord. The disease causes muscle wasting and paralysis and usually leads to death within $2-5$ years of its onset [1]. ALS patients can be classified into two groups: sporadic (ALSs) and familial (ALSf). ALSs represents about 90-95\% of cases while ALSf the remaining 5-10\% [2]. The average age at disease onset is ca. 60 years for the sporadic form and ca. 50 years for the family one [1]. It has a worldwide incidence of about 2 cases per 100,000 subjects and a prevalence that varies from 4 to 7 cases per 100,000 subjects [3], with uniform rates in Caucasian populations and lower rates in African, Asian, and Hispanic populations [4]. In most

Roberto Madeddu

rmadeddu@uniss.it

1 Department of Biomedical Science - Histology, University of Sassari, Sassari, Italy

2 National Institute of Biostructures and Biosystems, Rome, Italy

3 Department of Environment and Health, Istituto Superiore di Sanità, Rome, Italy studies, ALS is more common in men than women $[5,6]$. In European populations, the incidence of ALS has been estimated at 2.6-3.0 cases per 100,000 people [7]. Another paper reported the incidence of the disease in 10 countries of different geographical regions, and a higher prevalence was found in Uruguay, New Zealand, and the USA (age group was between 60 and 79 years) while a lower one in Serbia, China, and Taiwan. Besides, the same study estimated an increase in ALS cases worldwide of $69 \%$ from 2015 to 2040 [8]. A plethora of molecular and behavior-related mechanisms are implicated in the occurrence of ALS, but the causal event remains unknown. In particular, the main pathophysiological mechanisms that contribute to motor neuron degeneration in ALS are oxidative stress, mitochondrial dysfunction, axonal transport impairment, excitotoxicity, protein aggregation, endoplasmic reticulum stress, neuroinflammation, and abnormal RNA processing [9]. Furthermore, there is an epidemiological and clinical evidence that among the risk factors of the disease, there are viruses, cyanobacterial toxins, magnetic fields, several chemicals, and heavy metals [10]. Heavy metals are a particular chemical class of elements, without any biological role in the human body but with a harmful and toxic effect also at very low concentrations. Heavy metals are naturally present in the earth and human activity released them into the air, water, and food. Among them, cadmium (Cd) is a toxic 
element for the human body (the seven most dangerous substance for human health [11]), and the International Agency for Research on Cancer indicated $\mathrm{Cd}$ and $\mathrm{Cd}$ compounds carcinogenic for humans (group 1) [12]. Cadmium is a rare element in the crust with a concentration in the lithosphere of 0.08-0.1 ppm, and natural deposits of $\mathrm{Cd}$ are not present, but it is in combination with other materials to form minerals [13]. 9 Human exposure to $\mathrm{Cd}$ occurs by inhalation, ingestion, or through the skin, where it is poorly absorbed. In particular, inhalation is the main route of absorption of $\mathrm{Cd}$ or by occupational or by cigarette smoking exposures with the accumulation of $\mathrm{Cd}$ in the lung [14]. The amount absorbed through the intestine is accumulated in the body for a long time due to the almost absent mechanism of elimination from the body. The intestinal absorption is higher in people with zinc $(\mathrm{Zn})$, iron $(\mathrm{Fe})$, and calcium $(\mathrm{Ca})$ deficiency, conditions in which $\mathrm{Cd}$ uses its divalent nature to compensate for their absence [15]. After being absorbed, it is accumulated mainly in the liver and kidney [16]. Cadmium toxicity is involved in a high number of pathologies, both by direct and non-direct effect, also in the nervous system with accumulation in the brain due to its ability to bypass the blood brain barrier [17, 18]. In human autopsies of individuals with diverse neurodegenerative diseases, it was observed an important accumulation of $\mathrm{Cd}$ in locus ceruleus [19]. Furthermore, other authors reported the direct correlation of the professional exposure to $\mathrm{Cd}$ and the development of the ALS in a worker of Ni-Cd battery factory [20]. Exposure to metal can be acute and chronic; acute exposure can cause pulmonary edema, while chronic exposure can cause kidney and bone damages [21]. Besides, the harmful effects of $\mathrm{Cd}$ in cells are worthy of consideration; in fact, apoptosis and necrosis effects [22], implication in oxidative stress by reactive oxygen species (ROS) generation [23], lipids peroxidation [24], and break of the mitochondrial membrane $[25,26]$ have been observed. Furthermore, Cd altered gene expression [27] induces unbalances in $\mathrm{Ca}$ homeostasis [28], altered the $\mathrm{Zn}$ and $\mathrm{Cu}$ metabolism [29], and has a role in various types of human cancers [30-32]. Exposure to $\mathrm{Cd}$ had a serious and diversified impact on the functionality of the nervous system with symptoms including headache and vertigo, olfactory dysfunction, Parkinsonian-like symptoms, slowing of vasomotor functioning, peripheral neuropathy, decreased equilibrium, decreased ability to concentrate, and learning disabilities [18]. Again, exposure to the metal is associated with a decrease of bone mineral density, resulting in osteoporosis and increased risk of fractures [33]. Cadmium could carry out its pathogenic effect in ALS, also taking part in a wider multifactorial mechanism, such as the altered balance of essential metals [34-36].

In this review, publications about the role of Cd in ALS were taken into consideration, especially in the latest 10 years (2011-2020). The publications were selected from three different databases (PUBMED, SCOPUS, and SCIENCE
DIRECT), giving as keywords: "ALS Cd," "Amyotrophic Lateral Sclerosis Cd," "ALS Cadmium," "Amyotrophic Lateral Sclerosis Cadmium," and "Motor-Neuron Disease Cadmium." The research had produced about 900 articles; after careful analysis, which included reading the abstracts of all the articles found, we selected and included in our work only those articles that seemed appropriate to our research, excluding book chapters and reviews. The number of the papers is 9 for the epidemiological part (two of these were made before 2011) and 11 for the laboratory one. In this order, we tried to update the state of the art to elucidate the knowledge about epidemiology and the latest developments, on the potential etiological mechanisms of $\mathrm{Cd}$ in this pathology.

\section{Epidemiological studies on cadmium exposure in ALS patients}

Numerous studies have examined the effects of heavy metals on neurodegenerative diseases [37, 38]. Surveys have highlighted how the combination of geographical and epidemiological techniques was important for understanding the relationship between rare diseases and environmental exposure [39]. This fact linked with the unknown etiology of ALS leads researchers to speculate a relationship between the environment and its onset, including heavy metals. Exposure to heavy metals has been associated with the pathogenesis of ALS for over 150 years when heavy metals were detected in the tissues of patients with motor neuron diseases (MND) [40]. In Spain and France, three interesting studies have been carried out in the last 10 years to identify a relationship between exposure to environmental factors including heavy metals such as $\mathrm{Cd}$ and the onset of neurodegenerative diseases [39, 41, 42]. In particular, a French study analyzed the incidence of ALS within the region of Limousin, assessing the exposure of the population to environmental factors. It is interesting to note that municipalities with the highest number of ALS cases were more exposed to industrial activities; in fact, pulp and paper manufacturing industries have been significantly associated with a standardized incidence ratio (SIR) higher than 1 [41]. In 2018 in Spain, to identify the relationship between the occurrence of MND and exposure to heavy metals, the distribution of MND mortality rate in different municipalities over a period of 10 years was investigated by a spatial scale model [39]. The municipalities involved in the study were divided into exposed municipalities and unexposed municipalities, and results showed an increased risk of MND in exposed municipalities close to heavy metal emission sites. The study concluded that the combination of environmental emissions of different heavy metals including $\mathrm{Cd}$ (more than the single metal) was associated with a higher mortality rate $(15.4 \%)$ in exposed sites than in control sites [39]. In the same year in Spain, a nested case-control study 
was conducted consisting of a retrospective cohort covering the entire region of Catalonia. The purpose of the study was to assess the long-term exposure of subjects to pesticides and air pollutants, including $\mathrm{Cd}$, to understand whether the different geographical variations affected the occurrence of ALS. A linear association was found between $\mathrm{Cd}$ and the occurrence of ALS with an odds ratio $(\mathrm{OR})=1.332$. Furthermore, an association was observed between $\mathrm{Cd}$ and benzopyrene, suggesting the possible impact of industrial emissions on the ALS occurrence [42]. In addition to studies based on geographical and epidemiological models, other authors have analyzed the concentration of $\mathrm{Cd}$ in different biological matrices of ALS patients and have investigated on how they differ from controls [43-46]. The human biological matrices mostly used were blood (intra-erythrocitary, exposure for a period of time equal to the life of a red cell), urine (short-time exposure), hair or nails (medium or a long time of exposure because of the affinity of Cd with keratin), and cerebrospinal fluid (CSF that may indicate accumulation in the brain). Bocca et al. [44] quantified $\mathrm{Cd}$ in blood, hair, and urine of subjects affected by ALS and controls. All the individuals enrolled in the study were non-smokers and non-drinkers and had never been exposed to heavy metals during their working life, and none of them had metal prostheses. The study was conducted in Sardinia (an island region of Italy) because of its high prevalence of ALS (ca. 8 cases per 100,000 subjects) in comparison with other regions in the world [47]. Results indicated that the content of Cd remained unchanged in blood, hair, and urine by comparing ALS patients and healthy controls. Besides, in the ALS group, females had more hair $\mathrm{Cd}$ than males. The results showed that $\mathrm{Cd}$ levels in blood were positively associated with $\mathrm{Cd}$ levels in the hair $(p=0.018, \rho=0.400)$. However, the negative correlation between $\mathrm{Cd}$ content in hair and the duration of the disease did not prove the Cd-ALS relationship. The same ALS populations were sub-grouped accordingly to the severity of the disease. Results indicated that the patients with the more serious condition of the disease had blood $\mathrm{Cd}$ statistically higher than that in controls [46]. These two studies agree that the $\mathrm{Cd}$ is a neurotoxic metal [44], but that it is not directly involved in ALS; however, it can be a cause of concern if combined with other unleashed factors [46]. The research by Vinceti et al. [45] focused on the quantification of $\mathrm{Cd}$ in CSF of both ALS and control subjects, all living in the northern Italian region Emilia-Romagna. Concerning Cd results (exposure), the OR was decreased, while in the average tertile, it is higher, and the analysis for linear trend based on continuous values has confirmed an inverse association between exposure and risk [45]. Previously, the same authors analyzed the toenails of individuals affected by ALS and controls to measure concentrations of Cd [48]. This investigation, like the previous ones, did not suggest a key role of $\mathrm{Cd}$ in the etiology of pathology [48]. Again, concentrations of $\mathrm{Cd}$ in $\mathrm{CSF}$ and blood plasma were analyzed in patients from different regions of Norway [43]. In this case, the results showed that the CSF concentrations of $\mathrm{Cd}$ were higher in patients than in controls. This outcome seemed somehow to support an eventual involvement of Cd in ALS as reported also in previous studies. In 2001, Bar-Sela et al. [20] reported the case of a patient who died of ALS after 9 years of heavy professional exposure to $\mathrm{Cd}$. The patient had elevated levels of urinary $\mathrm{Cd}$ roughly two orders of magnitude greater than levels seen in the general population. Cadmium blood levels, usually, fall rapidly following cessation of exposure, while $\mathrm{Cd}$ blood levels in this patient were high even after 6 months of exposure. His Cd blood levels were higher than those of his peers. The proteinuria, as found in this case, is correlated with protracting exposures to $\mathrm{Cd}[20]$. Another study supporting the possible involvement of $\mathrm{Cd}$ in the pathogenesis of ALS was conducted in 2003 in the population of Guam [49]. In this study, the authors have determined the concentrations of $\mathrm{Cd}$, $\mathrm{Co}, \mathrm{Cu}, \mathrm{Fe}, \mathrm{Mn}, \mathrm{Rb}, \mathrm{V}$, and $\mathrm{Zn}$ in formalin-fixed brain tissue. The concentrations of $\mathrm{Cd}$ were markedly and significantly elevated both in gray and white matter in ALS patients, while for other metals, no significant differences were detected [49]. As above reported, analysis of different human matrices is useful to have information about the Cd level in the body, but results were often contradictory when compared with other studies performed on similar matrices. This can be related to diverse reasons as different habits, working activity, geographical position, different analytical techniques, and, last but not the least, a very low Cd concentration in a nonexposed population. This may indicate that $\mathrm{Cd}$ alone could not be able to initiate the ALS, but it is more realistic to think that it is part of a more complex synergic mechanism (Table 1).

\section{Cellular implication of cadmium in ALS models}

On a cellular level Cd causes cell death, by different mechanisms, such as inducing apoptosis [50,51], oxidative stress $[52,53]$, and by replacing essential metals at different levels for the cellular equilibrium by causing ions unbalancing [21] and by substituting them at levels of essentials proteins, such those involved in oxidative stress reduction, as $\mathrm{Cu}, \mathrm{Zn}$-SOD [54]. The etiological mechanisms of ALS are nowadays unclear, and the putative role of $\mathrm{Cd}$ in its insurgence and promotion is not effectively demonstrated, such as its putative mechanisms. In this section of the review, we report the last 10 years' updates about the cellular mechanisms of $\mathrm{Cd}$ imputable to its role in ALS.

Oxidative stress represents a pathological condition in which the oxidant and antioxidant species lose their equilibrium in the cells, causing the loss of cellular functionality, by chemical alteration and inactivation of strategical enzymes 
Table 1 Summary table of epidemiological studies conducted in the last 10 years, which relate the concentrations of Cd and other metals present within environmental, atmospheric and biological matrices

\begin{tabular}{|c|c|c|c|c|c|c|}
\hline $\begin{array}{l}\text { Year, authors } \\
{\left[\mathrm{n}^{\circ} \text { ref }\right]}\end{array}$ & Type of study & ALS patients & Controls & Other metals & Matrices & Country \\
\hline $\begin{array}{l}\text { 2011, Boumédiène } \\
\text { et al. [41] }\end{array}$ & Observational & 177 & - & $\mathrm{Pb}, \mathrm{Hg}, \mathrm{Al}, \mathrm{Se}, \mathrm{Mn}, \mathrm{Cu}, \mathrm{Fe}$ & Environment & Limousin, France \\
\hline $\begin{array}{l}\text { 2018, Sánchez-Díaz } \\
\text { et al. [39] }\end{array}$ & Observational & $\begin{array}{l}9434 \text { MND deaths in the } \\
\text { period 2007-2016 }\end{array}$ & - & $\mathrm{As}, \mathrm{Cr}, \mathrm{Cu}, \mathrm{Pb}, \mathrm{Hg}, \mathrm{Zn}$ & Rivers & Spain \\
\hline $\begin{array}{l}\text { 2018, Povedano } \\
\text { et al. [42] }\end{array}$ & $\begin{array}{l}\text { Observational: nested } \\
\text { case-control }\end{array}$ & 383 & 383 & $\mathrm{~Pb}, \mathrm{Hg}, \mathrm{Se}, \mathrm{Fe}, \mathrm{Mn}, \mathrm{Al}$ & Environment & Catalonia, Spain \\
\hline $\begin{array}{c}\text { 2015, Bocca et al. } \\
\text { [44] }\end{array}$ & $\begin{array}{r}\text { Observational: } \\
\text { case-control }\end{array}$ & 34 & 30 & $\mathrm{Al}, \mathrm{Pb}, \mathrm{Mn}, \mathrm{Hg}$ & $\begin{array}{l}\text { Blood, urine, } \\
\text { hair }\end{array}$ & Sardinia, Italy \\
\hline $\begin{array}{c}\text { 2018, Oggiano et al. } \\
{[46]}\end{array}$ & $\begin{array}{r}\text { Observational: } \\
\text { case-control }\end{array}$ & 34 & 30 & $\begin{array}{l}\mathrm{Al}, \mathrm{Pb}, \mathrm{Mn}, \mathrm{Hg}, \mathrm{Zn}, \mathrm{Cu} \\
\quad \mathrm{Ca}, \mathrm{Fe}, \mathrm{Se}, \mathrm{Mg}\end{array}$ & $\begin{array}{l}\text { Blood, urine, } \\
\text { hair }\end{array}$ & Sardinia, Italy \\
\hline $\begin{array}{l}\text { 2017, Vinceti et al. } \\
\text { [45] }\end{array}$ & $\begin{array}{r}\text { Observational: } \\
\text { case-control }\end{array}$ & 38 & 38 & $\mathrm{~Pb}, \mathrm{Hg}$ & CFS & $\begin{array}{l}\text { Emilia-Romagna, } \\
\text { Italy }\end{array}$ \\
\hline $\begin{array}{c}\text { 2013, Roos et al. } \\
{[43]}\end{array}$ & $\begin{array}{r}\text { Observational: } \\
\text { case-control }\end{array}$ & 17 & 10 & $\mathrm{Al}, \mathrm{Pb}, \mathrm{Mn}, \mathrm{Cu}, \mathrm{Mo}, \mathrm{V}, \mathrm{U}$ & CFS & Norway \\
\hline
\end{tabular}

that may cause cell death, as described in ALS and maybe at the base of the motor neuron death [21]. One of the mechanisms by which $\mathrm{Cd}$ causes oxidative stress is its capability to replace the $\mathrm{Zn}$ present in the superoxide dismutase (SOD) making it inactive. This alteration occurs in $10 \%$ of ALSf and $90 \%$ of ALSs. Huang et al. [21] observed the SOD concentration inhibition after $\mathrm{Cd}^{2+}$ addition at concentration > $500 \mathrm{nM}$, associated with a defective folding of the protein and $\mathrm{Zn}^{2+}$ decreased up to $1 / 7$, without the effects on $\mathrm{Cu}^{2+}$ concentration. The results confirmed the ability of $\mathrm{Cd}^{2+}$ to replace the $\mathrm{Zn}^{2+}$, due to its higher affinity for the locus. In the same study, the treatment of $\mathrm{N} 2 \mathrm{~A}$ cell line with $\mathrm{Cd}^{2+}$ showed an increment of expressions of metallothionein (MT), thioredoxin, and peroxiredoxins 1 and 6 , after $\mathrm{Cd}^{2+}$ treatment, justified by the authors as a protective mechanism against the oxidative stress induced by the high $\mathrm{Cd}^{2+}$ concentrations. The alteration of SOD and the consequent augmented expression of MT was observed also by Polykretis et al. [55], which purposed an alternative mechanism of SOD alteration by $\mathrm{Cd}^{2+}$, suggesting that $\mathrm{Cd}^{2+}$ induces $\mathrm{Zn}$-SOD precipitation by the formation of an intermolecular disulfide bond [55]. Another way to induce oxidative stress in ALS is by induction

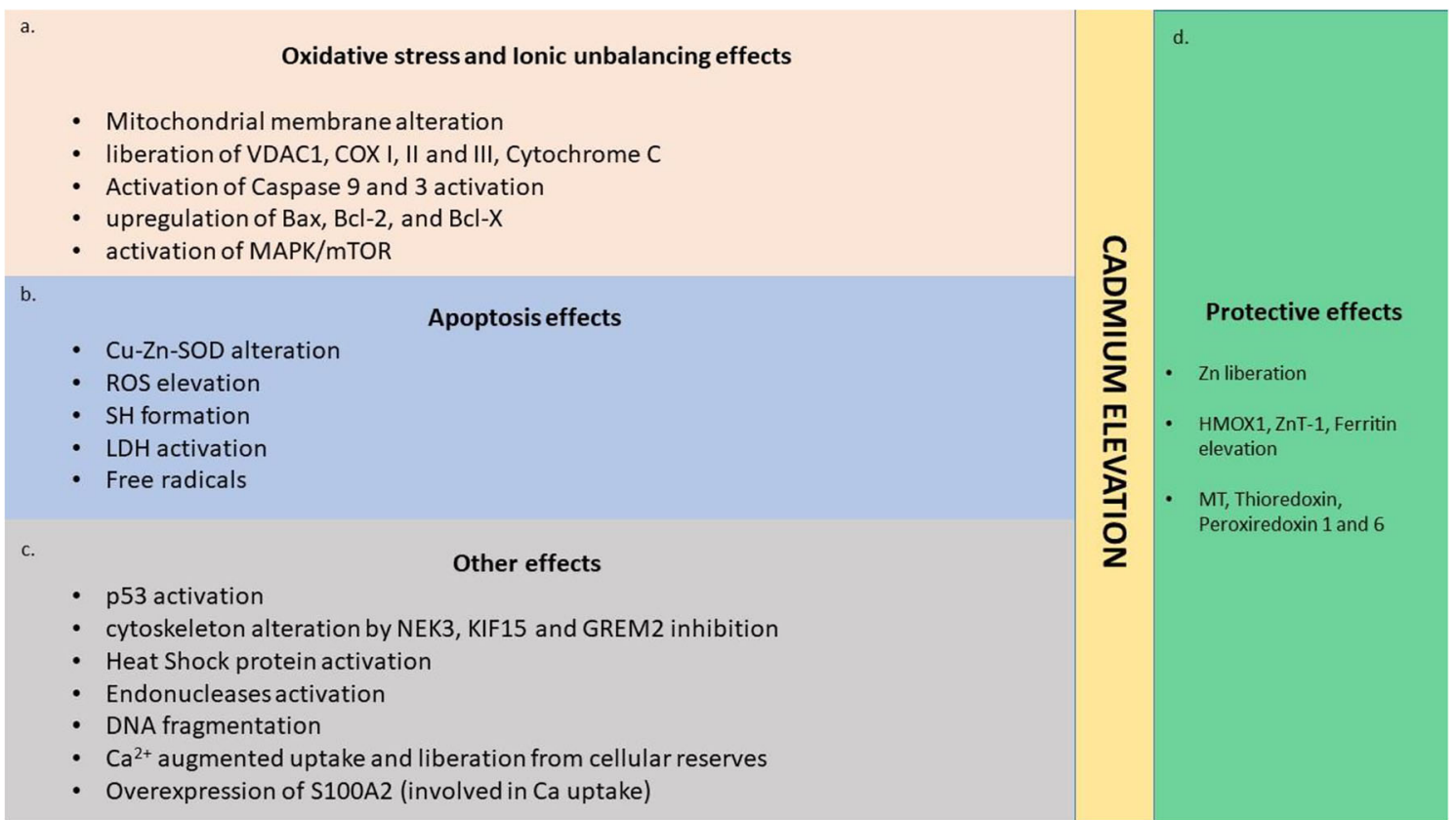

Fig. 1 Graphical representation of the Cd's effects on the motor-neuron. Each panel indicates the effect in a specific area of cellular damage: a oxidative stress and ionic unbalancing, b apoptosis, and $\mathbf{c}$ other effects; (d) shows the protective mechanisms induced in the cell to respond to the insult of cadmium 
of ROS, which naturally occurs in the cells, but an excessive production compromises cellular antioxidant defenses, with consequent free radical damage to cellular lipids, proteins, and nucleic acids. The ability of $\mathrm{Cd}^{2+}$ to induce ROS formation 36 times in respect to $\mathrm{Na}^{2+}$ and $\mathrm{Mg}^{2+}$ was demonstrated by Pogue et al. [56], in an in vitro model of ALS. To this end, Rahman et al. [54] studied the effect of $\mathrm{Cd}^{2+}$ on PC12 (neuron model), demonstrating its ability to induce ROS formation, and the increment of SH groups and LDH activity, phenomena reverted by the $\mathrm{Zn}^{2+}$ addiction. Otherwise, the excessive concentration of $\mathrm{Zn}^{2+}(500 \mu \mathrm{mol} / \mathrm{L})$ showed a synergic toxic effect with $\mathrm{Cd}^{2+}[54]$. Another mechanism by which $\mathrm{Cd}^{2+}$ induces cell damage is apoptosis. The induction of motor neuron apoptosis was demonstrated by the augmented VDAC1, a mitochondrial channel protein, involved in the induction of apoptosis, and the decreased of PDI, a protein, involved in the apoptosis outcome [21]. The above-cited study of Rahman et al. [54] showed that a concentration of $\mathrm{Cd}^{2+}$ at $5 \mu \mathrm{mol} / \mathrm{L}$ was sufficient to induce apoptosis and DNA fragmentation by activating endonucleases, and caspase 9 , while a concentration of $10 \mu \mathrm{mol} / \mathrm{L}$ was necessaire to induce upregulation of cytochrome c, Bax, Bcl-2, and Bcl-X. The authors demonstrated the protective effect of $\mathrm{Zn}$ at a low concentration by restoring the $\mathrm{Cd}^{2+}$ induced alteration. Otherwise, when the $\mathrm{Zn}^{2+}$ was used at a concentration of $500 \mu \mathrm{mol} / \mathrm{L}$, it shows a synergic effect with $\mathrm{Cd}^{2+}$ to induce cellular damage, by alteration of the mitochondrial function [54].

As seen before, $\mathrm{Cd}^{2+}$ is involved in the ionic unbalancing. In particular, the interaction between $\mathrm{Cd}^{2+}$ and $\mathrm{Ca}^{2+}$ has been widely studied, to understand if this could play a role in the damage of motor neurons and in the development and progression of ALS. In vitro and animal studies demonstrated that augmented concentration of $\mathrm{Cd}^{2+}$ induces elevation of $\mathrm{Ca}^{2+}$ concentration by its release from intracellular storage and by extracellular uptake [28]. The consequence of the intracellular increase of $\mathrm{Ca}^{2+}$ was cell death induction, with MAPK/mTOR activation, dysfunction of cytochrome oxidase subunits (COX-I/II/III), depletion of mitochondrial membrane potential, cleavage of caspase-9, caspase-3, and poly (ADP-ribose) polymerase (PARP); oxidative stress induction with ROS levels elevation [28, 57]; both the process were inhibited after $\mathrm{Ca}^{2+}$ chelation $[28,57]$. Furthermore, it was observed that $\mathrm{Cd}^{2+}$ induces the overexpression of S100A2, a Ca ${ }^{2+}$-binding protein with an essential role that mediates signal transduction and diseases in the nervous system, such as multiple sclerosis, Parkinson, and ALS [58]. Taken together, these results indicate $\mathrm{Ca}^{2+}$ as a fundamental mediator of $\mathrm{Cd}^{2+}$ in its negative neuronal effect. The effect on glia, in particular on astrocytes, has been tested by Ospondpant et al. [59], demonstrating how intracellular $\mathrm{Cd}^{2+}$ increase, decrease the glutathione levels, increase $\mathrm{Ca}^{2+}$ content, altering mitochondrial membrane state end activate the JNK and PI3k/Akt pathways, to induce astrocyte apoptosis. The ability of $\mathrm{Cd}^{2+}$ to induce apoptosis and cell cycle arrest is analyzed in this study, and the authors observed that $\mathrm{Cd}^{2+}$ concentrations $>20 \mu \mathrm{M}$ induce DNA fragmentation, Bcl2 downregulation, and Bax upregulation and the promotion of $\mathrm{p} 53, \mathrm{p} 27$, and $\mathrm{p} 21$ [59]. In conclusion, the idea of an involvement of $\mathrm{Cd}$ among the behavioral components implicated in the ALS insurgence seems to be supported by the literature of in vitro models, with different mechanisms such as alteration of antioxidants, cell cycle, and cell fate system, to induce motor neuron cell death (Fig. 1).

\section{Conclusion}

Amyotrophic lateral sclerosis is a fatal neurodegenerative disease of unknown origin. Many hypotheses have been released of different origins as environmental and/or genetics, but none of them resulted conclusively. Among the possible factors, some heavy metals, such as $\mathrm{Cd}$, are known to be neurotoxicant. In the last decades, studies were performed to verify if the Cd was able to promote the ALS. The data presented until now do not allow to attribute the direct involvement of Cd in ALS, but at the same time, it cannot be excluded. The role of Cd in ALS may be identified in a synergic multifactorial mechanism, in which it plays an important but probably replaceable role; other studies are necessary to better elucidate this eventual involvement in this pathology, such as studies of cellular assets in patients.

Acknowledgements Open access funding provided by Università degli Studi di Sassari within the CRUI-CARE Agreement.

\section{Compliance with ethical standards}

Conflict of interest None.

Ethical approval None.

Open Access This article is licensed under a Creative Commons Attribution 4.0 International License, which permits use, sharing, adaptation, distribution and reproduction in any medium or format, as long as you give appropriate credit to the original author(s) and the source, provide a link to the Creative Commons licence, and indicate if changes were made. The images or other third party material in this article are included in the article's Creative Commons licence, unless indicated otherwise in a credit line to the material. If material is not included in the article's Creative Commons licence and your intended use is not permitted by statutory regulation or exceeds the permitted use, you will need to obtain permission directly from the copyright holder. To view a copy of this licence, visit http://creativecommons.org/licenses/by/4.0/.

\section{References}

1. Wijesekera LC, Leigh PN (2009) Amyotrophic lateral sclerosis. Orphanet J Rare Dis 4:3. https://doi.org/10.1186/1750-1172-4-3 
2. Chen S, Sayana P, Zhang X, Le W (2013) Genetics of amyotrophic lateral sclerosis: an update. Mol Neurodegener 8:28. https://doi.org/ 10.1186/1750-1326-8-28

3. Chiò A, Logroscino G, Traynor BJ, Collins J, Simeone JC, Goldstein LA, White LA (2013) Global epidemiology of amyotrophic lateral sclerosis: a systematic review of the published literature. Neuroepidemiology 41:118-130. https://doi.org/10.1159/ 000351153

4. Cronin S, Hardiman O, Traynor BJ (2007) Ethnic variation in the incidence of ALS: a systematic review. Neurology 68:1002-1007. https://doi.org/10.1212/01.wnl.0000258551.96893.6f

5. Mehta P, Kaye W, Bryan L, Larson T, Copeland T, Wu J, Muravov O, Horton K (2016) Prevalence of amyotrophic lateral sclerosis United States, 2012-2013. MMWR Surveill Summ 65:1-12. https://doi.org/10.15585/mmwr.ss6508a1

6. Marin B, Boumédiene F, Logroscino G, Couratier P, Babron MC, Leutenegger AL, Copetti M, Preux PM, Beghi E (2017) Variation in world wide incidence of amyotrophic lateral sclerosis: a metaanalysis. Int J Epidemiol 46:57-74. https://doi.org/10.1093/ije/ dyw061

7. Logroscino G, Traynor BJ, Hardiman O, Chiò A, Mitchell D, Swingler RJ, Millul A, Benn E, Beghi E, EURALS (2010) Incidence of amyotrophic lateral sclerosis in Europe. J Neurol Neurosurg Psychiatry 81:385-390. https://doi.org/10.1136/jnnp. 2009.183525

8. Arthur KC, Calvo A, Price TR, Geiger JT, Chiò A, Traynor BJ (2016) Projected increase in amyotrophic lateral sclerosis from 2015 to 2040. Nat Commun 7:12408. https://doi.org/10.1038/ ncomms 12408

9. Mancuso R, Navarro X (2015) Amyotrophic lateral sclerosis: current perspectives from basic research to the clinic. Prog Neurobiol 133:1-26. https://doi.org/10.1016/j.pneurobio.2015.07.004

10. Vinceti M, Bottecchi I, Fan A, Finkelstein Y, Mandrioli J (2012) Are environmental exposures to selenium, heavy metals, and pesticides risk factors for amyotrophic lateral sclerosis? Rev. Environ Health 27:19-41. https://doi.org/10.1515/reveh-2012-0002

11. The ATSDR 2019 Substance Priority List (2019) https://www. atsdr.cdc.gov/spl/index.html

12. IARC, International Agency for Research on Cancer (2012) Arsenic, metals, fibers and dusts. Volume 100C. A review of human carcinogens. IARC monographs

13. Cullen JT, Maldonado MT (2013) Biogeochemistry of cadmium and its release to the environment. Met Ions Life Sci 11:31-62. https://doi.org/10.1007/978-94-007-5179-8 2

14. Järup L, Åkesson A (2009) Current status of cadmium as an environmental health problem. Toxicol Appl Pharmacol 238:201-208. https://doi.org/10.1016/j.taap.2009.04.020

15. Nordberg GF, Nogawa K, Nordberg M (2015) Chapter 32 Cadmium. In: Nordberg GF, Fowler BA, Nordberg M (eds) Handbook on the toxicology of metals. Elsevier, Amsterdam, pp 445-486

16. Ebert-McNeill A, Clark SP, Miller JJ, Birdsall P, Chandar M, Wu L, Cerny EA, Hall PH, Johnson MH, Isales C, Chutkan N, Bhattacharyya MH (2012) Cadmium intake and systemic exposure in postmenopausal women and age-matched men who smoke cigarettes. Toxicol Sci 130:191-204. https://doi.org/10.1093/toxsci/ kfs 226

17. Al-Saleh I, Shinwari N (2001) Levels of cadmium, lead, and mercury in human brain tumors. Biol Trace Elem Res 79:197-203. https://doi.org/10.1385/BTER:79:3:197

18. Wang B, Du Y (2013) Cadmium and its neurotoxic effects. Oxidative Med Cell Longev 2013:898034. https://doi.org/10. 1155/2013/898034

19. Pamphlett R, Bishop DP, Jew SK, Doble PA (2018) Age-related accumulation of toxic metals in the human locus ceruleus. PLoS One 13:e0203627. https://doi.org/10.1371/journal.pone.0203627
20. Bar-Sela S, Reingold S, Richter ED (2001) Amyotrophic lateral sclerosis in a battery-factory worker exposed to cadmium. Int $\mathrm{J}$ Occup Environ Health 7:109-112. https://doi.org/10.1179/ 107735201800339470

21. Huang YH, Shih CM, Huang CJ, Lin CM, Chou CM, Tsai ML, Liu TP, Chiu JF, Chen CT (2006) Effects of cadmium on structure and enzymatic activity of $\mathrm{Cu}, \mathrm{Zn}-\mathrm{SOD}$ and oxidative status in neural cells. J Cell Biochem 98:577-589. https://doi.org/10.1002/jcb. 20772

22. López E, Figueroa S, Oset-Gasque MJ, González MP (2003) Apoptosis and necrosis: two distinct events induced by cadmium in cortical neurons in culture. Br J Pharmacol 138:901-911. https:// doi.org/10.1038/sj.bjp.0705111

23. Chen L, Liu L, Huang S (2008) Cadmium activates the mitogenactivated protein kinase (MAPK) pathway via induction of reactive oxygen species and inhibition of protein phosphatases $2 \mathrm{~A}$ and 5 . Free Radic Biol Med 45:1035-1044. https://doi.org/10.1016/j. freeradbiomed.2008.07.011

24. Shukla A, Shukla GS, Srimal RC (1996) Cadmium-induced alterations in blood-brain barrier permeability and its possible correlation with decreased microvessel antioxidant potential in rat. Hum Exp Toxicol 15:400-405. https://doi.org/10.1177/ 096032719601500507

25. Al-Nasser IA (2000) Cadmium hepatotoxicity and alterations of the mitochondrial function. J Toxicol Clin Toxicol 38:407-413. https:// doi.org/10.1081/clt-100100950

26. Cannino G, Ferruggia E, Luparello C, Rinaldi AM (2009) Cadmium and mitochondria. Mitochondrion 9:377-384. https:// doi.org/10.1016/j.mito.2009.08.009

27. Koizumi S, Yamada H (2003) DNA microarray analysis of altered gene expression in cadmium-exposed human cells. J Occup Health 45:331-334. https://doi.org/10.1539/joh.45.331

28. Yuan Y, Jiang CY, Xu H, Sun Y, Hu FF, Bian JC, Liu XZ, Gu JH, Liu ZP (2013) Cadmium-induced apoptosis in primary rat cerebral cortical neurons culture is mediated by a calcium signaling pathway. PLoS One 8:e64330. https://doi.org/10.1371/journal.pone. 0064330

29. Zhang D, Gao J, Zhang K, Liu X, Li J (2012) Effects of chronic cadmium poisoning on $\mathrm{Zn}, \mathrm{Cu}, \mathrm{Fe}, \mathrm{Ca}$, and metallothionein in liver and kidney of rats. Biol Trace Elem Res 149:57-63. https://doi.org/ 10.1007/s12011-012-9394-9

30. Hartwig A (2013) Cadmium and cancer. Met Ions Life Sci 11:491507. https://doi.org/10.1007/978-94-007-5179-8_15

31. Luevano J, Damodaran C (2014) A review of molecular events of cadmium-induced carcinogenesis. J Environ Pathol Toxicol Oncol 33:183-194. https://doi.org/10.1615/jenvironpatholtoxicoloncol. 2014011075

32. Rapisarda V, Miozzi E, Loreto C, Matera S, Fenga C, Avola R, Ledda C (2018) Cadmium exposure and prostate cancer: insights, mechanisms and perspectives. Front Biosci (Landmark Ed) 23: 1687-1700. https://doi.org/10.2741/4667

33. Buha A, Jugdaohsingh R, Matovic V, Bulat Z, Antonijevic B, Kerns JG, Goodship A, Hart A, Powell JJ (2019) Bone mineral health is sensitively related to environmental cadmium exposureexperimental and human data. Environ Res 176:108539. https:// doi.org/10.1016/j.envres.2019.108539

34. Sutedja NA, Veldink JH, Fischer K, Kromhout H, Heederik D, Huisman MH, Wokke JH, van den Berg LH (2009) Exposure to chemicals and metals and risk of amyotrophic lateral sclerosis: a systematic review. Amyotroph Lateral Scler 10:302-309. https:// doi.org/10.3390/ijms140815286

35. Trojsi F, Monsurro MR, Tedeschi G (2013) Exposure to environmental toxicants and pathogenesis of amyotrophic lateral sclerosis: state of the art and research perspectives. Int J Mol Sci 14:1528615,311. https://doi.org/10.3390/ijms140815286 
36. Forte G, Bocca B, Oggiano R, Clemente S, Asara Y, Sotgiu MA, Farace C, Montella A, Fois AG, Malaguarnera M, Pirina P, Madeddu R (2017) Essential trace elements in amyotrophic lateral sclerosis (ALS): results in a population of a risk area of Italy. Neurol Sci 38:1609-1615. https://doi.org/10.1007/s10072-017-3018-2

37. Jaishankar M, Tseten T, Anbalagan N, Mathew BB, Beeregowda KN (2014) Toxicity, mechanism and health effects of some heavy metals. Interdiscip Toxicol 7:60-72. https://doi.org/10.2478/intox2014-0009

38. Ingre C, Roos PM, Piehl F, Kamel F, Fang F (2015) Risk factors for amyotrophic lateral sclerosis. Clin Epidemiol 7:181-193. https:// doi.org/10.2147/CLEP.S37505

39. Sánchez-Díaz G, Escobar F, Badland H, Arias-Merino G, de la Paz MP, Alonso-Ferreira V (2018) Geographic analysis of motor neuron disease mortality and heavy metals released to rivers in spain. Int J Environ Res Public Health 15:2522. https://doi.org/10.3390/ ijerph 15112522

40. Roos PM (2017) Chapter 10 - metals and motor neuron disease. In: White AR, Aschner M, Costa LG, Bush AI (eds) Biometals in neurodegenerative diseases: mechanisms and therapeutics. Academic Press, pp 175-193

41. Boumédiène F, Druet-Cabanac M, Marin B, Preux PM, Allée P, Couratier P (2011) Contribution of geolocalisation to neuroepidemiological studies: incidence of ALS and environmental factors in Limousin, France. J Neurol Sci 309:115-122. https://doi. org/10.1016/j.jns.2011.07.002

42. Povedano M, Saez M, Martínez-Matos JA, Barceló MA (2018) Spatial assessment of the association between long-term exposure to environmental factors and the occurrence of amyotrophic lateral sclerosis in Catalonia, Spain: a population-based nested casecontrol study. Neuroepidemiology 51:33-49. https://doi.org/10. $1159 / 000489664$

43. Roos PM, Vesterberg O, Syversen T, Flaten TP, Nordberg M (2013) Metal concentrations in cerebrospinal fluid and blood plasma from patients with amyotrophic lateral sclerosis. Biol Trace Elem Res 151:159-170. https://doi.org/10.1007/s12011-0129547-x

44. Bocca B, Forte G, Oggiano R, Clemente S, Asara Y, Peruzzu A, Farace C, Pala S, Fois AG, Pirina P, Madeddu R (2015) Level of neurotoxic metals in amyotrophic lateral sclerosis: a populationbased case-control study. J Neurol Sci 359:11-17. https://doi.org/ 10.1016/j.jns.2015.10.023

45. Vinceti M, Filippini T, Mandrioli J, Violi F, Bargellini A, Weuve J, Fini N, Grill P, Michalke B (2017) Lead, cadmium and mercury in cerebrospinal fluid and risk of amyotrophic lateral sclerosis: a casecontrol study. J Trace Elem Med Biol 43:121-125. https://doi.org/ 10.1016/j.jtemb.2016.12.012

46. Oggiano R, Solinas G, Forte G, Bocca B, Farace C, Pisano A, Sotgiu MA, Clemente S, Malaguarnera M, Fois AG, Pirina P, Montella A, Madeddu R (2018) Trace elements in ALS patients and their relationships with clinical severity. Chemosphere 197: 457-466. https://doi.org/10.1016/j.chemosphere.2018.01.076

47. Logroscino G, Traynor BJ, Hardiman O, Chiò A, Couratier P, Mitchell JD, Swingler RJ, Beghi E, EURALS (2008) Descriptive epidemiology of amyotrophic lateral sclerosis: new evidence and unsolved issues. J Neurol Neurosurg Psychiatry 79:6-11. https:// doi.org/10.1136/jnnp.2006.104828

48. Bergomi M, Vinceti M, Nacci G, Pietrini V, Brätter P, Alber D, Ferrari A, Vescovi L, Guidetti D, Sola P, Malagu S, Aramini C, Vivoli G (2002) Environmental exposure to trace elements and risk of amyotrophic lateral sclerosis: a population-based case-control study. Environ Res 89:116-123. https://doi.org/10.1006/enrs. 2002.4361

49. Gellein K, Garruto RM, Syversen T, Sjøbakk TE, Flaten TP (2003) Concentrations of $\mathrm{Cd}, \mathrm{Co}, \mathrm{Cu}, \mathrm{Fe}, \mathrm{Mn}, \mathrm{Rb}, \mathrm{V}$, and $\mathrm{Zn}$ in formalinfixed brain tissue in amyotrophic lateral sclerosis and Parkinsonism-dementia complex of Guam determined by highresolution ICP-MS. Biol Trace Elem Res 96:39-60. https://doi. org/10.1385/BTER:96:1-3:39

50. Sarchielli E, Pacini S, Morucci G, Punzi T, Marini M, Vannelli GB, Gulisano M (2012) Cadmium induces alterations in the human spinal cord morphogenesis. BioMetals 25:63-74. https://doi.org/ 10.1007/s10534-011-9483-9

51. He W, Li Y, Tian J, Jiang N, Du B, Peng Y (2015) Optimized mixture of $\mathrm{As}, \mathrm{Cd}$ and $\mathrm{Pb}$ induce mitochondria-mediated apoptosis in C6-glioma via astroglial activation, inflammation and P38MAPK. Am J Cancer Res 5:2396-2408

52. Bonomi F, Ganadu ML, Lubinu G, Pagani S (1994) Reversible and non-denaturing replacement of iron by cadmium in Clostridium pasteurianum ferredoxin. Eur J Biochem 222:639-644. https://doi. org/10.1111/j.1432-1033.1994.tb18907.x

53. Nair AR, DeGheselle O, Smeets K, Van Kerkhove E, Cuypers A (2013) Cadmium-induced pathologies: where is the oxidative balance lost (or not)? Int J Mol Sci 14:6116-6143. https://doi.org/10. 3390/ijms14036116

54. Rahman MM, Ukiana J, Uson-Lopez R, Sikder MT, Saito T, Kurasaki M (2017) Cytotoxic effects of cadmium and zinc coexposure in PC12 cells and the underlying mechanism. Chem Biol Interact 269:41-49. https://doi.org/10.1016/j.cbi.2017.04.003

55. Polykretis P, Cencetti F, Donati C, Luchinat E, Banci L (2019) Cadmium effects on superoxide dismutase 1 in human cells revealed by NMR. Redox Biol 21:101-102. https://doi.org/10.1016/ j.redox.2019.101102

56. Pogue AI, Jones BM, Bhattacharjee S, Percy ME, Zhao Y, Lukiw WJ (2012) Metal-sulfate induced generation of ROS in human brain cells: detection using an isomeric mixture of 5- and 6carboxy-2', $7^{\prime}$-dichlorofluorescein diacetate (carboxy-DCFDA) as a cell permeant tracer. Int J Mol Sci 13:9615-9626. https://doi. org/10.3390/ijms 13089615

57. Xu B, Chen S, Luo Y, Chen Z, Liu L, Zhou H, Chen W, Shen T, Han X, Chen L, Huang S (2011) Calcium signaling is involved in cadmium-induced neuronal apoptosis via induction of reactive oxygen species and activation of MAPK/mTOR network. PLoS One 6:e19052. https://doi.org/10.1371/journal.pone.0019052

58. Forcella M, Lau P, Oldani M, Melchioretto P, Bogni A, Gribaldo L, Fusi P, Urani C (2020) Neuronal specific and non-specific responses to cadmium possibly involved in neurodegeneration: a toxicogenomics study in a human neuronal cell model. Neurotoxicology 76:162-173. https://doi.org/10.1016/j.neuro. 2019.11.002

59. Ospondpant D, Phuagkhaopong S, Suknuntha K, Sangpairoj K, Kasemsuk T, Srimaroeng C, Vivithanaporn P (2019) Cadmium induces apoptotic program imbalance and cell cycle inhibitor expression in cultured human astrocytes. Environ Toxicol Pharmacol 65:53-59. https://doi.org/10.1016/j.etap.2018.12.001

Publisher's note Springer Nature remains neutral with regard to jurisdictional claims in published maps and institutional affiliations. 